\title{
Appraising a Research Collection
}

Mr. Rogers is director, The Grosvenor Library, Buffalo, N.Y.

\section{Introduction}

This report on methods and results of an appraisal of the Grosvenor Library is offered for three reasons:

I. To present per volume insurance values, by Library of Congress classes, for a research collection of approximately one-half million volumes,

2. To present a new method of applying processing costs to total holdings in order to arrive at a practical per volume insurance value,

3. To present processing costs, particularly in regard to phonograph records, which may be of interest to other libraries.

The Grosvenor Library is a non-circulating reference and research library established in 1859 . The collection is especially strong in bibliography, literature, history (with emphasis on local and American history), genealogy, fine arts, and music (including sheet music, phonograph records, and definitive editions of major composers). There is also a Medical Department containing approximately 15,000 older books and journals, but current emphasis is now placed on an effective, up-to-date working collection of $5000-8000$ volumes in that field.

\section{Method}

The appraisal described here was completed in July, 1950, and was based on the "first method" recommended by Dorothea Singer on p. 33-34 of The Insurance of
Libraries (American Library Association, 1946). Only one part of this method, that pertaining to binding, was not considered applicable. For the most part, Grosvenor Library binding funds have been devoted to binding the current intake of journals, and inasmuch as the Grosvenor is a noncirculating library, its books are not subject to the wear that those in a conventional circulating library are. Although binding expenditures were not specifically and objectively considered, the physical condition of books was kept in mind in applying depreciation factors, as may be seen in the footnotes to Table I.

For those who may not have a copy of Miss Singer's book easily available, the procedure for computing insurance values involves:

a. A per volume count, by class or subclass, of the collection, either from the shelves (if all books are in) or from the shelf list. Both methods were used in this appraisal.

b. The careful spot pricing of books at equal intervals throughout each class. We priced 5,298 volumes in accordance with this sampling technique, plus the volume by volume pricing of certain rare and valuable books. In most classes, every fiftieth volume was priced, but in a few homogeneous classes every onehundredth volume. Prices were taken from accession and order records extending from 1947 to 1863 . Where such information was not available, volumes were priced from second-hand catalogs or, in a limited number of cases, by staff specialists in the various subject fields. Figures prepared by the Insurance Committee of the American Library Association (ALA Bulletin, Vol. 38, Oct. 1944, 
Table 1

Computation of per Volume and per Class Insurance Values

\begin{tabular}{|c|c|c|c|c|c|c|c|}
\hline Column I & Column 2 & Column 3 & Column 4 & Column 5 & Column 6 & Column 7 & Column 8 \\
\hline Library Classification & $\begin{array}{l}\text { Num- } \\
\text { ber of } \\
\text { Vols. }\end{array}$ & $\begin{array}{c}\text { Average } \\
\text { Original } \\
\text { Cost or } \\
\text { Value } \\
\text { per } \\
\text { Volume }\end{array}$ & $\begin{array}{l}\text { Deprecia- } \\
\text { tion and } \\
\text { Obsoles- } \\
\text { cence or } \\
\text { Apprecia- } \\
\text { tion } \\
\text { (Per Cent) }\end{array}$ & $\begin{array}{l}\text { Adjusted } \\
\text { Average } \\
\text { Current } \\
\text { Value } \\
\text { per } \\
\text { Volume }\end{array}$ & $\begin{array}{c}\text { Proc- } \\
\text { essing } \\
\text { Factor } \\
\text { (See } \\
\text { Table } \\
\text { III) }\end{array}$ & $\begin{array}{c}\text { Per } \\
\text { Volume } \\
\text { Insurance } \\
\text { Value } \\
\text { Including } \\
\text { Processing } \\
\text { Factor }\end{array}$ & $\begin{array}{c}\text { Total } \\
\text { Insurance } \\
\text { Values } \\
\text { by Class }\end{array}$ \\
\hline A-General Works & 6,834 & $\$ 2.38$ & -15 & $\$ 2.02$ & $\$ .116$ & $\$ 2.136$ & $\$ I_{4}, 597.42$ \\
\hline B-Philosophy & 22,821 & 2.27 & -40 & I. 36 & .208 & I. 568 & $35,783.32$ \\
\hline $\begin{array}{l}\text { C-History-Auxiliary } \\
\text { Sciences }\end{array}$ & 8,366 & $4 \cdot 50$ & $+\mathrm{I}_{5}$ & 5.17 & .256 & $5 \cdot 426$ & $45,393 \cdot 9^{2}$ \\
\hline $\begin{array}{c}\text { D- History and Topogra- } \\
\text { phy except America }\end{array}$ & 35,836 & $2 \cdot 4^{2}$ & -15 & 2.05 & .368 & 2.418 & $86,651 \cdot 44$ \\
\hline $\mathrm{E}$-America & 12,868 & $2 . \mathrm{I}_{4}$ & None & 2. $\mathrm{I}_{4}$ & .513 & 2.653 & $34, \mathrm{I} 38.80$ \\
\hline $\mathrm{F}$-America & 18,915 & 3.33 & +11 & 3.70 & .254 & 3.954 & $74,789 \cdot 91$ \\
\hline $\begin{array}{l}\text { G- Geography, Anthro- } \\
\text { pology }\end{array}$ & 5,292 & 2.72 & -45 & 1.50 & .447 & I. 947 & $10,303 \cdot 52$ \\
\hline $\mathrm{H}$-Social Science & $3^{8}, 164$ & I. 75 & -20 & I. 40 & $\cdot 313$ & I. 713 & $65,374 \cdot 93$ \\
\hline J-Political Science & 13,539 & 1.60 & None & 1.60 & .321 & 1.921 & $26,008 \cdot 42$ \\
\hline $\mathrm{K}-\mathrm{Law}$ & I, 54 I & I. 73 & -40 & I. 04 & .245 & I. 285 & $\mathrm{I}, 980.18$ \\
\hline L-Education & 8,435 & 1.60 & -15 & I. 36 & $\cdot 368$ & I. 728 & $14,575.68$ \\
\hline M-Music & 12,026 & 2.95 & None & 2.95 & .224 & 3.174 & $3^{8}, 170.52$ \\
\hline $\mathrm{N}$-Fine Arts & I $8,88 \mathrm{I}$ & 6.88 & None & 6.88 & .747 & 7.627 & $144,005 \cdot 38$ \\
\hline $\mathrm{P}$-Language \& Literature & 61,210 & I. 55 & -15 & I. 32 & .108 & I. 428 & $87,407.88$ \\
\hline Q-Science & 22,730 & 2.44 & -20 & I. 95 & $\cdot 317$ & 2.267 & $51,528.91$ \\
\hline $\mathrm{R}$-Medicine & 8,829 & 3.62 & -50 & I. $8 \mathrm{I}$ & .279 & 2.089 & $18,443.78$ \\
\hline S-Agriculture & 8,552 & I. 84 & $-\mathrm{I} 5$ & I. 56 & .470 & 2.030 & $17,360 \cdot 56$ \\
\hline $\mathrm{T}-\mathrm{T}$ echnology & 24 , OI 3 & 2.17 & -40 & $1 \cdot 30$ & .402 & I. 702 & $40,870 \cdot 12$ \\
\hline $\begin{array}{l}\text { U-V-Military and Naval } \\
\text { Science }\end{array}$ & 3,755 & I. 63 & - IO & 1.47 & $\cdot 323$ & I. 793 & $6,73^{2} \cdot 7^{1}$ \\
\hline $\begin{array}{l}\mathrm{Z}-\text { Bibliography and Li- } \\
\text { brary Science }\end{array}$ & 8,609 & 3.28 & -10 & 2.95 & .116 & 3.066 & $26,395 \cdot 19$ \\
\hline
\end{tabular}

Explanation of Column 4. Table I

Following are some of the important considerations which affected our decisions in regard to the figures in Column 4. Notes are arranged by L. C. class letters:

Twenty-five per cent of this collection consists of almanacs which have maintained or increased in value since purchase. Many of our encyclopedias would also cost somewhat more than original purchase price.

Approximately ten per cent of this class comprises magazines which are valued at ALA insurance figures and therefore are not subject to further depreciation. Many standard works and the unusual and valuable Shaker collection are also in this class. These considerations are offset by the extensive amount of inspirational literature.

Many books in this class have doubled or more than doubled in value since time of purchase. The fifteen per cent appreciation is considered particularly moderate in view of current costs of books in this field.

$$
\text { D \& E }
$$

The physical condition and basic nature of books in these classes led several department heads to advocate a five to fifteen per cent appreciation for them, but it was decided to use a more conservative valuation.

F

In view of current costs of books in this field, the excellence of our collection and the fact that these books are likely to increase rather than decrease in value, an eleven per cent appreciation is regarded as low rather than high.

The strength of this class has not been maintained. Many of the books are out of date.

H

Almost fifty per cent of this class is government document material priced with ALA insurance values not subject to further depreciation. The twenty per cent depreciation is therefore greater than it might appear.

This class is predominantly made up of government documents priced at ALA insurance values.

K

Despite the substantial amount of government document material in this class forty per cent depreciation was applied because of the weakness of the non-document material.

Periodicals priced at ALA insurance values constitute much of this class; therefore, fifteen per cent depreciation applied to the whole class is larger than it might appear.

The depreciation in half of this class has been at least offset by appreciation of the remainder of the class. The excellence of our music collection and the current cost of books in this field make the evaluation conservative. $\mathrm{N}$

This is an excellent collection containing an unusual number of oversize books. Our failure to appreciate this class is a compromise between current cost factors and the condition of the collection on one hand and the exceptional nature of the collection on the other. 
$P$

The fifteen per cent depreciation of this class reduces the unit price well below the ALA average for adult non-fiction, but there is enough fiction represented in the class, despite the fact that we buy practically no fiction, to warrant the lower figure. On the other hand sets of standard authors and reference books have kept us from using a greater depreciation figure.

$$
\text { Q }
$$

A twenty per cent depreciation was considered adequate because of the number of documents and periodicals for which ALA insurance values were used and because many of the books are basic science books of historical significance. $\mathbf{R}$

Fifty per cent depreciation is excessive when applied to the current collection, but the high figure was used in view of the many older non-periodical volumes.

$\mathrm{S}$

This class contains many government documents priced at ALA insurance values and several exceptional special collections (early sporting books and books on gardening).

Standard works in technology and special collections, e.g., cook books, keep the value of this class as high as it is despite lack of current buying in this field.

Much of this material is of historical interest including military costume books of great value.

Z

The depreciation of this class represents a compromise between a substantial appreciation in the bibliography section and a substantial depreciation in the library science section.

Table II

Appraisal of Catalogs, Indexes and Specially Classified or Unclassified Library Materials

\begin{tabular}{|c|c|c|c|}
\hline Column I & Column 2 & Column 3 & Column 4 \\
\hline Description of Items & $\begin{array}{l}\text { Number of Vols. } \\
\text { Unless Otherwise } \\
\text { Stated }\end{array}$ & $\begin{array}{l}\text { Unit } \\
\text { Insurance } \\
\text { Value }\end{array}$ & $\begin{array}{l}\text { Total } \\
\text { Insurance } \\
\text { Value }\end{array}$ \\
\hline Congressional Series & 7,416 & $\$ 1.00^{*}$ & $\$ 7,416.00$ \\
\hline U. S. Patent Specifications & 9,309 & $2.00^{*}$ & I 8,6 I 8.00 \\
\hline U. S. Patent Gazettes and Indexes & 824 & $2.00^{*}$ & $1,648.00$ \\
\hline British and Canadian Patents & 792 & $1.00^{*}$ & 792.00 \\
\hline $\begin{array}{l}\text { Magazines (General and Medical not else- } \\
\text { where classified) }\end{array}$ & & & \\
\hline Bound & 27,046 & $3.00^{*}$ & $8 \mathrm{I}, \mathrm{I} 38.00$ \\
\hline $\begin{array}{l}\text { Unbound } \\
\text { Newspapers }\end{array}$ & I, 768 & 2.00 & $3,536.00$ \\
\hline $\begin{array}{l}\text { Newspapers } \\
\text { Before } 1800\end{array}$ & $\mathrm{I}, 224$ issues & $3.00^{*}$ & $3,672.00$ \\
\hline $1800-1820$ & 209 issues & $\begin{array}{l}3.00 \\
.75^{*}\end{array}$ & $\begin{array}{r}3,072.00 \\
156.75\end{array}$ \\
\hline $1820-1840$ & 614 issues & $.50^{*}$ & 307.00 \\
\hline $1840-1865$ & 19,665 issues & $.25^{*}$ & $4,916.25$ \\
\hline $1865-1947$ & 84,188 issues & . 10* & $8,418.80$ \\
\hline Fixed Classification & 2,483 & I. $46^{*}$ & $3,625.18$ \\
\hline $\begin{array}{l}\text { League of Nations Documents } \\
\text { Rare Books }\end{array}$ & 3,591 & & $2,139.00^{4}$ \\
\hline $\begin{array}{l}\text { Rare Books } \\
\text { Microfilm }\end{array}$ & $\begin{array}{l}5,366^{1} \\
504 \text { spools }\end{array}$ & & $\begin{array}{l}81,935.60 \\
5,577.00^{4}\end{array}$ \\
\hline Phonograph records & 13,262 records & $1 \cdot 39^{2}$ & $18,434,18$ \\
\hline $\begin{array}{l}\text { Boston Evening Transcript genealogy col- } \\
\text { umns mounted in scrapbooks ( } 40 \text { years) }\end{array}$ & $14 \mathrm{I}$ & 35.00 & $4,935.00$ \\
\hline $\begin{array}{l}\text { Index to Boston Evening Transcript geneal- } \\
\text { ogy column, in 16-inch special oversize } \\
\text { binders }\end{array}$ & 10 & 350.00 & $3,500.00$ \\
\hline $\begin{array}{l}\text { Hartford Times genealogy columns mounted } \\
\text { in scrapbooks }\end{array}$ & 23 & 35.00 & 805.00 \\
\hline $\begin{array}{l}\text { Index to Hartford Times genealogy column } \\
\text { in 16-inch special oversize binders }\end{array}$ & 6 & 500.00 & $3,000.00$ \\
\hline Main Card Catalog and Shelflist ${ }^{3}$ & $\begin{array}{l}\text { Approximately } \\
\mathrm{I}, 300,000 \text { cards }\end{array}$ & & $\begin{array}{l}\$ 78,000 \text { with microfilm } \\
\text { of shelflist }(\$ 496,000\end{array}$ \\
\hline $\begin{array}{l}\text { Departmental Card Catalogs and Indexes } \\
\text { Not Otherwise Listed }\end{array}$ & 400,000 cards & & $24,000.00$ \\
\hline
\end{tabular}

Explanatory Notes-Table II

* Figures in Column 3 followed by an asterisk are insurance values suggested by the Insurance Committee of the American Library Association (ALA Bulletin, Vol. 38 (October 1944), p. 369). Depreciation and obsolescence have been considered in arriving at these values,

1 Individually priced.

2 The unit insurance value for phonograph records comprises \$r.00 per record average replacement cost plus \$0.39"per record for processing (see Table IV).

3 The valuation of the library's card catalogs is based on figures as to card reproduction and filing costs cited in R, B

Downs, Union Catalogs in the United States, Chicago. ALA, 1942.

+ Cost price. 
Table III

Computation of Processing Factor

\begin{tabular}{|c|c|c|c|c|c|c|c|c|c|}
\hline \multicolumn{10}{|c|}{ Column } \\
\hline I & 2 & 3 & 4 & 5 & 6 & 7 & 8 & 9 & 10 \\
\hline 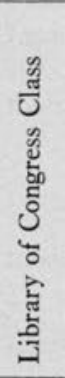 & 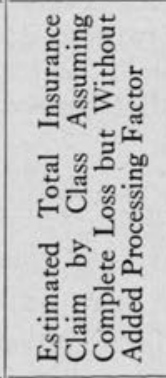 & 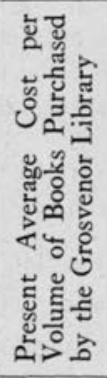 & 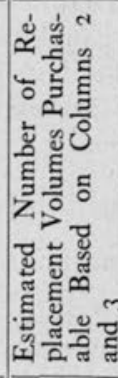 & 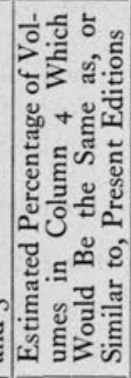 & 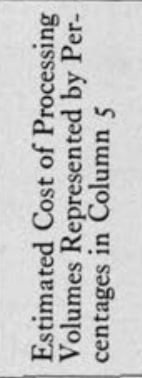 & 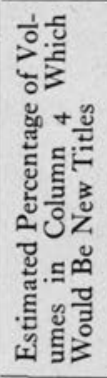 & 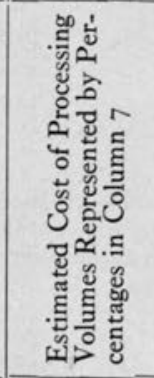 & 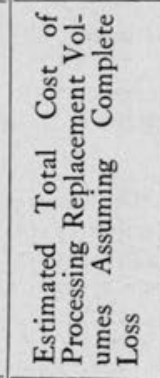 & 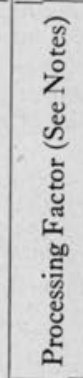 \\
\hline A & $\$ 13,804.68$ & $\$ 8.00$ & 1,725 & $75 \%$ & $\$ 258.75$ & $25 \%$ & $\$ \quad 534.75$ & 793.50 & $\$ .116$ \\
\hline B & $3^{1}, 03^{6} \cdot 5^{6}$ & 3.00 & 10,345 & 75 & $\mathrm{I}, 55 \mathrm{I}$ & 25 & $3,206.95$ & $4,758.70$ & .208 \\
\hline C & $43,252.2$ & 6.13 & 7,055 & 90 & 1,269 & Io & & $2,144.7^{2}$ & .256 \\
\hline D & $73,463.80$ & 4.00 & 18,265 & 50 & 1,836 & 50 & $11,386$. & ${ }^{1} 3,222.80$ & .368 \\
\hline E & $27,537 \cdot 5^{2}$ & 3.00 & 9,179 & & 917 & 50 & 5,690 . & $6,608.88$ & .513 \\
\hline $\mathrm{F}$ & $69,985.50$ & 5.93 & 11,801 & 80 & $1,888.16$ & 20 & 2,9 & $4,8 \mathrm{I}_{4} .80$ & .254 \\
\hline G & $7,93^{8} .00$ & 3.29 & 2,412 & 25 & 120.60 & 75 & $2,243 \cdot 16$ & $2,363 \cdot 76$ & .447 \\
\hline $\mathrm{H}$ & $53,429.60$ & 3.22 & 16,593 & 50 & $1,659.30$ & 50 & $10,287.66$ & II, 946.96 & .313 \\
\hline$J$ & $21,662.40$ & 3.0 & 7,056 & 60 & 846. & 40 & $3,499.77$ & $4,346.49$ & $.32 \mathrm{i}$ \\
\hline $\mathrm{K}$ & $\mathrm{I}, 602.64$ & $4.8 \mathrm{i}$ & & 10 & & $9 \circ$ & & & .245 \\
\hline L & $11,471.60$ & 3.04 & 3,773 & 40 & 301.84 & 60 & $2,807.11$ & $3,108.95$ & .368 \\
\hline M & 3 & & 5,873 & 75 & 880. & 25 & 1,820 & & .224 \\
\hline $\mathrm{N}$ & $129,901.28$ & 6.63 & & 50 & $1,959 \cdot 30$ & 50 & $12, I_{4}$ & $14,106.96$ & .747 \\
\hline $\mathrm{P}$ & $80,797.20$ & 3.71 & 778 & 90 & $3,920.04$ & 10 & 2,7 & $6,620.51$ & .108 \\
\hline Q & 323.50 & & 10,028 & 50 & $1,002.8$ & 50 & 6,2 & $7,220.16$ & .317 \\
\hline $\mathrm{R}$ & & 6.68 & & 20 & & 80 & & & .279 \\
\hline $\mathrm{S}$ & I. 12 & 3.42 & 3,900 & 20 & 156.00 & 80 & $3,868.80$ & $4,024.80$ & .470 \\
\hline $\mathrm{T}$ & 0.90 & & & 20 & 374.96 & 80 & 9,299 . & $9,673.96$ & .402 \\
\hline & & 3.28 & 1,682 & 50 & 168.20 & 50 & $\mathrm{I}, \mathrm{O}_{42} 2.84$ & $1,211.04$ & .323 \\
\hline Z & $25,396 \cdot 55$ & $7 \cdot 7^{2}$ & 3,289 & 90 & 592.02 & I0 & 407.84 & 999.86 & .116 \\
\hline
\end{tabular}

Explanatory Notes for Table III

Column 3-Figures are based on 1948 and 19.4 purchases.

Column 5-These estimated percentages are based on the combined judgment of five key staff members. The nature of the Grosvenor Library and the availability of books in the second hand market have been considered in arriving at these figures.

Column 6-Figures in this column are computed in the following manner: Number of volumes in Column $4 \times$ Percentage in Column $5 \times$ \$ .20 where $\$ 0.20$ is the average cost of preparing and adding a volume when the same or similar edition is in the library. (See Table IV.) This computation is independent of the value of the card catalog and is based on the assumpthe card catalog is suitably insured, with or without a microfilm of the shelfist.

Column 8-Figures in this column are computed in the following manner: Number of volumes in Column $4 \times$ Percentage in Column $7 \times \$ 1.24$ where $\$ 1.24$ is the average cost per volume for cataloging in the Grosvenor Library. (See Table IV.) Column 9-Figures in this column are the sum of figures in Columns 6 and 8 .

Column 10-Figures in this column are computed by dividing Column 9 of this table by the corresponding figures in Column 2 of Table I. This reduces the anticipated processing cost to the same terms as corresponding figures in Column 5 of Table I, thereby making possible a per volume insurance value wbich includes the processing factor and which can be applied to total present holdings as represented in Column 2, Table I.

p. 369) were used for periodicals and government documents with certain exceptions. In this connection, it is important to note that our government documents and our periodicals, other than general and medical periodicals, are classified according to the L. C. system.

c. Application of depreciation, obsolescence and appreciation factors. This involves a certain amount of judgment, and information such as is listed in the footnotes to Table I.

d. Addition of the cost of processing. For this purpose, we developed the processing factor in Table III, the results of which are recorded in Column 6 of Table I. The first step in Table III was to compute the approximate insurance which 
Table IV

Processing Costs-Grosvenor Library

Books

(Based on the entire year 1949)

Salaries and wages chargeable to cataloging

Cost of Library of Congress printed cards

Cost of plain cards

Cost of stencils

Number of volumes cataloged (Includes 2,322 volumes originally cataloged and 7,443 volumes recataloged)

Per volume average cost
$\$ 17,804.86$

$2,140.00$

77.00

58.00

$\$ 20,079.86$

16,098

$\$ 1.24$

\section{Phonograph Records}

(Based on the processing of 89 records, June 1950)

\begin{tabular}{lrrr}
\hline \multicolumn{1}{c}{ Operation } & Hours & \multicolumn{1}{c}{$\begin{array}{c}\text { Cost per } \\
\text { Hour }\end{array}$} & $\begin{array}{r}\text { Total } \\
\text { Cost }\end{array}$ \\
\hline Cataloging & 13.75 & $\$ 1.60$ & $\$ 22.00$ \\
Typing added entries & 7.66 & 1.20 & 9.19 \\
Labeling & 2.33 & 1.20 & 2.80 \\
Revising & .75 & 1.60 & 1.20 \\
\cline { 2 - 4 } & & & $\$ 35.19$
\end{tabular}

Unit cost

$\$ 0.395$

would be collected, assuming coverage based on the number of volumes in Column 2, Table I, and the per volume values listed in Column 5, Table I. The next steps were to compute the number of replacement volumes we could buy at present prices with the insurance money and to estimate as intelligently as possible the percentage of the replacement volumes which would be essentially the same as present editions. These estimates were made by staff members who were thoroughly familiar with their subject fields, who had 20-30 years experience in this library, and who were well acquainted with the second-hand market. Once we had determined the degree of identity which was likely to obtain between a replacement collection and the present one, we made two computations (Column 6 and 8 of Table III), the one being the total cost of processing replacement volumes similar to present editions, and the other, the cost of processing replacement volumes which would be new to the collection. For processing costs, we used current experience as computed in Table IV. Total estimated processing costs of replacement volumes were then reduced to a factor (Column 10, Table III) which could be applied to total present holdings but which would reflect the cost of processing a smaller replacement collection.

\section{Explanation of Method}

Our failure to use a flat $\$ 1.24$ per present volume as a processing cost may be questioned. However, this would be unrealistic in terms of the number of volumes which would be purchasable with the insurance money, assuming an extensive loss. It also makes no distinction between replacements which would be essentially the same as, and those which would be different from, present editions. No library can be careless about funds, and the use of the flat \$I.24 per volume would send total insurance and total premiums skyrocketing. The attempt here is to be practical without grossly overor under-insuring.

Several situations are possible in the event of an extensive loss, and each contingency must be considered in developing the insurance program.

a. Part or all of the card catalog and shelf list might be destroyed and the book collection remain intact.

b. Part or all of the collection might be lost without destruction of the card catalog.

c. Both catalog and collections might be wholly or partially destroyed.

It is especially important to understand that the use of the processing factor as developed in Table III is based on the assumption that the card catalog will be

a. Protected by microfilm (in our case, a microfilm of the shelf list). ${ }^{1}$

1 The microfilm of the shelf list also provides a basis for making a claim in the event of loss. 
b. Separately insured with or without a microfilm. (In the latter instance, much more insurance is required. We decided that three years' premiums would be so much greater without the protection afforded by a film that the film would pay for itself in that time).

Some of the per volume insurance values in Column 7, Table I, may appear high in comparison with some of the insurance values suggested by ALA, but consideration of two factors should modify this impression. First, one should compare the figures in Column 7, Table I, with the corresponding figures in Column 3, Table III, the latter being the present cost (after substantial discounts) of books purchased by this library. Secondly, there are many valuable books standing on the general shelves of the Grosvenor Library which have been covered only by the sampling technique. In 1950 alone, we transferred twenty-five titles with a total value of $\$ 3300.00$ from our general collection to the Rare Book Room. This project, which has only been started, is continuing with equally impressive results.

\section{Sequence of Tables}

With this general introduction, it is hoped that the tables with their accompanying notes will be largely self-explanatory. It is suggested that Table I be read through Column 5 ; then Tables III and IV in their entirety; and finally, Columns 6-8 of Table I, and Table II.

\section{Insurance Evaluation of a University Library's Collections}

\section{(Continued from page 23)}

in which library property is located for the purpose of keeping waste paper, packing boxes, and other inflammables cleared out.

\section{Conclusion}

In insuring a university library's collections, the primary consideration is the securing of coverage which, in the event of the loss by fire of all or part of the holdings, would provide funds for the replacement of the items lost, at or close to present purchase costs. The rarities and other items of high monetary value should be given allrisk protection by being placed under a Fine Arts policy. To secure the maximum benefits which may be desired and to secure them at the lowest premium rate which will be consistent with security, it is advisable to keep in close touch with a reputable, experienced insurance broker, agent, or firm. By so doing, helpful counsel will be assured during the planning stage, during the evaluation, and during the later months and years whenever problems connected with insurance arise.

The responsibility laid on the Librarian for computing the insurance values of the collections of a large library is heavy. However, with teamwork by the staff specialists in the various subject fields and with expert insurance counsel, a sound insurance program which will provide reasonable protection against all major risks can readily be worked out. 